\title{
Subjective Language Accommodation in Official Twitter Account of Tirto.id
}

\author{
Avicenna Raksa Santana ${ }^{1}$, Ahmad Mulyana ${ }^{2}$ \\ \{avicenna.r.s@gmail.com ${ }^{1}$, ahmad.mulyana@mercubuana.ac.id² \\ Universitas Mercubuana, Jakarta, Indonesia ${ }^{12}$
}

\begin{abstract}
This study aims to describe the use of subjective language in Tirto.id's Twitter account. The theory used in this research is accommodation theory, with a phenomenological approach and qualitative methods. In this study, it is known that Tirto.id accommodates subjective language styles-which are commonly used by Twitter users - to create fluid or familiar situations for readers. However, that language style is not used to deliver all news. News containing issues of sexual violence, violence in Papua, terrorism, and other human rights violations, for example, is conveyed using formal language. Thus, it appears that there are two accommodation strategies carried out, namely convergence and divergence. Tirto.id does not always use a convergence strategy (subjective language), because there are important issues that need to be addressed using formal language (divergence), which reflects the legitimacy of Tirto.id as a media institution.
\end{abstract}

Keywords: Subjective Language, Accommodation Theory, News Website, Twitter

\section{Introduction}

Now is the era of online media, and in the future, world of communication will be changed, and one of the new players who will dominate is integrated smart electronic devices [1]. For now, in the context of mass communication, online media is the answer. According to the records of the commercial marketing technology company Criteo (2018), online media has been growing (2014-2017), and it is much faster than the growth of advertisements on television and other media. In the midst of such situations, Tirto.id was founded. Tirto.id is news site, which provide articles and infographics in Indonesia. Tirto.id was founded by A. Sapto Anggoro who also serves as Editor in Chief and CEO. The presentation of Tirto.id's writings include the rubric of mild reports, in-depth, hard news, current issues, and Tirto Visual Report (TVR). Tirto.id is the first media to pass International Fact-Checking (IFCN) verification.

Today, Tirto.id has $618.4 \mathrm{~K}$ followers on Twitter. For the number of followers on Twitter, Tirto.id is still behind most of its competitors, although it is superior to kumparan.com $(524.7 \mathrm{~K})$ - which is founded roughly the same time as Tirto.id. Looking at the following statistics on social media, we might be able to get some insights. However, apart from these numbers, there is one thing that is uniquely representing Tirto.id. That is the style of delivery on social media, especially Twitter, which uses subjective language styles. Tirto.id can easily write tweet like "JIAaaakHHHkkhHh $\sim$ " to deliver news. They also frequently use emoticons, which are generally used for informal conversations in chat. Emoticons are string of symbols 
representing body language in text-based communication [2] that are prevalent in certain genres of CMC, including Twitter [3]. Besides emoticons, Tirto.id also uses punctuation, but not in formal way. Punctuation functions, such as tilde $(\sim)$, are used incompatible with normal functions. The tilde, which should be used to describe estimation, is used to describe the intonation, which should use an ellipsis (...). So far, no media in Indonesia has done that, except Tirto.id.

Tirto.id's Twitter account has previously been researched, but not specifically for its use of subjective language. Research made by Paramastri and Gumilar (2019) talked more at the general pattern of Tirto's use of Twitter. According to their study, Tirto.id uses Twitter because of the speed and ease of spreading news and the possibility of making two-way communication. In detail, the research describes how Tirto.id makes use of Twitter accounts, not only to disseminate, but also to gather news material and monitor criticism from readers. Paramastri and Gumilar explained:

"The divisions whose work is related to the use of Twitter are the Editorial Team and the Social Media Team. The editorial team, especially the journalists, use Twitter for the news gathering process. Meanwhile, the Marketing and Social Media teams were authorized to become the administrator of the Tirto.id's Twitter account. The performance of the two is closely related. The work process was preceded by a planning meeting on Monday to discuss projections of news issues. The reporter then uses Twitter to raise the issue and look for sources before the news is written and checked by the editor. The finished news will be spread by the administrator via Twitter with a break every 30 minutes. The audience response, in the form of criticism or suggestions for the news, will be conveyed by the administrator to the editorial team at the evaluation meeting. The policy will re-adjust according to the evaluation." [4]

This research tries to have deeper understanding in which Paramastri and Gumilar described as: "... the finished news will be spread by the administrator via Twitter". To do that, we use accommodation theory. In general, the communication accommodation theory (CAT) says that to be socially accepted, people often adapt and change their way of communication in a linguistic scope (e.g. speech speed, accent), paralinguistic (e.g. pause, length of speech), and nonverbal (such as smile, gaze) [5]. At first glance, accommodation theory may indeed be difficult to be applied in mass communication, considering that the communicator (sender) and communicant (receiver) do not interact directly. Even so, accommodation in mass communication can occur by considering two things.

First, even though there is no direct conversation, beliefs and stereotypes about message recipients and their speech patterns can become practical materials for the message maker accommodation process. In fact, the speaker or message maker often accommodates not the way the recipient speaks, but the stereotype of the way the recipient believes the message he believes [6]. Even if there is input from the audience, it will practically only add to or complement the stereotypes that will be used in the future, not the present.

Second, the absence of a direct audience response makes communicators more focused on producing their own language [7]. Therefore, it is rare for messages from the media to be made by only one person. The production of messages from a medium is more often done by several individuals, such as writers, editors, producers, operators, and so on. Most of these people are employed for one main purpose, namely observing and modifying each other's message production [8]. Thus, the accommodation process is also very possible, in which coworkers adjust each other's language. 
It is clear then that accommodation can also occur in mass communication, by referring to the stereotyping of the audience and the collective monitoring of independent messages by media workers. At this point, it becomes important to know two types of accommodation strategies, namely convergence and divergence [5]. Convergence is a strategy in which a people adjust their communication behavior to be more similar to others, while divergence is a communication strategy to highlight the differences. In this study, it can be said that convergence occurs when Tirto.id's Twitter account uses subjective language, while divergence occurs when Tirto.id's Twitter account uses formal language that shows its authority as a press.

To understand this phenomenon, several topics have been reviewed. The first topic that has been reviewed was regarding the editorial policy of mass media for social media-right here, it is important to pay attention to the transition from "mass media logic" to "social media logic". The next important topic to be talked is about applying the logic of social media in presenting news. After that, there is also a review about the accommodation theory which is used in this research.

As a press institution, media has an editorial policy as a guideline. The link between social media and editorial policy has been studied by Mike Ananny (2014) in "Networked Press Freedom and Social Media: Historical Tracing and Contemporary Forces in PressPublic Relations". The study analyzed social media policies and guidelines for eight Englishlanguage news media: The Associated Press, the British Broadcasting Corporation, the Canadian Broadcasting Corporation, ESPN, the Los Angeles Times, NPR, Reuters, and the Washington Post. As a result, four major themes were found: 1) motivations for using social media; 2) negotiating personal and professional identities; 3) adopting social media logics; 4) and bracketing transparency. From the four themes, Mike Ananny then got a number of interesting findings about how mass media and journalists adapt to social media platforms. However, this study has various limitations, one of which is the absence of findings on how the policies or guidelines were applied.

"To be sure, this study has limitations. First, focusing on official and publicly available social media policies means missing organizational practices, informal heuristics, and context-specific negotiations that surely reflect how news organizations understand and use social media in practice. This study has little to say about how closely these policies are followed." [9] [10]

Understanding how guidelines are followed is one thing, the other thing-which is also important-is understanding the relation betweet guidelines and the social media logic behind it. One of the studies that talked about the application of social media logic is "Presenting News on Social Media" by Welbers \& Opgenhaffen (2018). Welbers \& Opgenhaffen state that the logic of social media is built on the logic of virality, which is one way to get it (viral) is by embedding emotions [11]. It is stated in the article that "emotionally charged Twitter messages tend to be retweeted more often and more quickly compared to neutral ones" [12]. Therefore, "subjectivity"- which can attract emotionsbecame the focus of Welbers \& Opgenhaffen's research. They explained that:

“... we focus on how news organizations use subjective language in Facebook status messages to respond to the media logic of that platform. This ties in to a current discussion regarding how the traditional concept of media logic, now sometimes referred to as mass 
media logic, relates to the 'norms, strategies, mechanisms and economies' of social media platforms, that constitute a social media logic."

However, the subjective language news organization uses have to be familiar to their audiences. The strategies, then, is not only using subjective language, but also accommodating the way people talking in social media. Understanding how someone accommodating other people language style is one of the main topic in accommodation theory. The accommodation theory was coined by Howard Giles in the 1970s. At first, the theory was not known as the communication accommodation theory (CAT), but the speech accommodation theory (SAT). SAT is used to explain the motivation behind a person's shifting speech style when meeting other people. More specifically, SAT is formulated to understand a person's cognitive and affective processes when converging and diverging in speech (Thakerar et al., 1982). A decade after initiated, SAT was widely adopted, so then Giles (1987) renamed the SAT to CAT.

According to Riordan, Markman, and Stewart (2012), communication accommodation theory (CAT) is indeed more widely used for research that focuses on face-to-face communication [13]. Even so, along with its development, CAT can actually also be used to examine computer-mediated communication (CMC). Lexical convergence in CMC, for example, has been found in the use of polite words in e-mail [14] and gender-specific conversations in CMC channels (Herring, 1996; Thomson, 2006; Thomson, Muracher, \& Green, 2001). Even for mass communication, accommodation theory can also be used.

"We have seen that mass communication is very different from a situation where speakers are continuously adjusting their language production as they monitor their interlocutors' reactions and production and evaluate their own production. Most media content is also not ad lib speech, but is scripted in whole or in part. It might be better, then, discussed in terms of communication accommodation, a broader label suggested by Giles et al. (1987) and elaborated in Coupland and Giles (1988)." [15]

The changes from SAT to CAT have opened opportunity to understand broader issues. As mentioned by Baumeister (1993) and Giles \& Street (1994), this change introduced the process of self-presentation and impression management [16]. Today, those two thingsself-presentation and impression management-are relevant not only in face-to-face communication, but also in social media.

\section{Research Method}

This research is a qualitative research with a phenomenological approach. The qualitative method was chosen because it can provide a detailed, complex picture from the participant's point of view. For the approach, I used a phenomenological approach, because I wanted to see the phenomenon in depth from the perspective of the related subject. This study used purposive sampling (or often called purposeful sampling). According to Creswell, in purposive sampling, researchers intentionally determine the most suitable participants to study or understand a phenomenon to be studied [17]. In this study, researchers chose Tirto.id's social media specialist, Irfan Satryo Wicaksono. Satryo is the person who coordinates the four social media administrators at Tirto.id. 


\section{Results and Discussion}

\subsection{Text Analysis}

On behalf of the social media team, Satryo admitted that Tirto.id did use informal style of communication. The idea to use informal style came from administrators, who then conveyed it to Editor in Chief - and approved. The reason Tirto.id social media team use informal style is so that Tirto.id can be closer to its readers. Satryo said:

"Tujuannya adalah untuk memberi persona kepada akun Tirto.id. Keberadaan persona di akun media sosial akan menciptakan relasi yang cair dan karib.”

"The goal is to make persona for Tirto.id. This social media persona will make a friendly and fluid relation."

The term "persona" Satryo used is actually the same as "self-presentation"; it explains that Tirto.id wants to present theirself as friendly and fun media. They also try to achieve certain kind of impression from their audience, and this is the reason why Tirto.id even presents a personified figure, namely Pak Tirto. Satryo said:

"Penciptaan sosok Pak Tirto sebagai ikon dilakukan untuk memberi kesan bahwa yang membagikan tautan bukan akun robot, tapi sosok yang punya beragam emosi: bisa gemas, bisa kesal, bisa sedih, dan melucu."

"The creation of Pak Tirto as an icon was done to give the impression that the one who shared the link was not a robot, but a person who has various emotions: can be upset, can be mad, can be sad, and can be funny."

It is interesting, then, to see the use of subjective language in this part. It's been said previously, there are two accommodation strategies: convergence and divergence. Convergence is a strategy to adjust communication behavior to be more similar to other people, while divergence is a communication strategy to highlight differences with other people. Both can be seen from how Tirto.id uses subjective language. Satryo mentioned that:

“... tak semua cuitan boleh memakai gaya santai. Ada artikel-artikel [terkait] kasus kekerasan seksual, kekerasan di Papua, terorisme, dan problem pelanggaran hak asasi lain yang tidak boleh dibawakan dengan gaya [santai] seperti ini."

“... not all tweets can be made casually. There are articles [related] to cases of sexual violence, violence in Papua, terrorism, and other human rights violations that should not be brought up in such [casual] style."

Tirto.id's choice to not use subjective language in addressing these issues suggests a divergence accommodation strategy. At that point, the administrators, while fully understanding the language style of the Twitter audience in general, chose to differentiate the language style. They did consciously highlight their identity as a press agency. The reason behind this distinction, according to Satryo, is the attitude of the editorial staff. 
"Sebelum mencuitkan sebuah artikel, administrator perlu mengetahui sikap redaksi dalam artikel tersebut: pro, kontra, atau netral. Dan, ini wajib. Dari situ, mulai disusun bahasa yang akrab agar netizen lebih mudah mencerna sikap redaksi ini."

"Before tweeting an article, administrators need to know the attitude of the editorial staff in the article: pro, contra, or neutral. And, this is mandatory. From there, a familiar language began to be drawn up so that it would be easier for netizens to digest this editorial attitude."

When raising issues involving vulnerable groups, Tirto.id tends to use divergence accommodation strategies, so that marginalized group unrest can be taken seriously by the public. Meanwhile, when raising, for example, the badness of the government or corporations, the administrator of Tirto.id does not hesitate to make subjective remarks, so that Tirto.id's voice feels almost identical to the voice of the public in general. Thus, however subjective, what the admin tweeted was still a representative of Tirto.id's attitude.

It is clear that Tirto.id applies what Welbers \& Opgenhaffen (2018) calls a subjective language. As previously mentioned, subjective, fluid and emotionally charged language, can attract the attention of the audience more (Stieglitz and Dang-Xuan, 2013; Klinger 2013). By using subjective language, there is a presence of a private state, which refers to a person's opinion, emotion, or view [18]. This subjective language, and the private state it brings, however, doesn't always appear in every Tirto.id's tweets.

The use of subjective language by Tirto.id then also opened the topic of discussion regarding press freedom. The question of whether the media has the right to have an opinion is an important topic. Before the era of social media, it's been known that media opinion can be seen from the gesture newscaster [19]. In the era of social media, the use of language may be a new indication of media views. This is very interesting to study, but this research focuses more on the subjective language accommodation made by Tirto.id, not the attitudes, views, or ideology of Tirto.id itself, so that there is still more room for further research on this matter.

\section{Conclusions}

Tirto.id uses subjective language to give the impression of being familiar with the audience - something that is effective according to reviews of other studies. This subjective language style is used as long as it is politically correct, and does not attack certain vulnerable groups. Meanwhile, for sensitive issues, the accommodation strategy applied is divergence, which Tirto.id shows its legitimacy as a press institution.

In applying subjective language, administrators must first know the attitude of the editorial staff. Next, this attitude is processed into a tweet that accommodates (convergence) everyday language. The use of subjective language then open private state where Tirto.id's views on certain issues are shown. But, unfortunately, there is no-yet - explanation about Tirto.id's opinion, or even ideology, behind every tweets. That is another topic to be examined in another research.

\section{References}

[1] L.-V. Szabo, "The Future of Communication: From new Media to Postmedia," Procedia - Soc. Behav. Sci., 2014.

[2] S. Coats, "Grammatical feature frequencies of English on Twitter in Finland," in English in 
Computer-Mediated Communication, 2016.

[3] T. Schnoebelen, "Do You Smile with Your Nose? Stylistic Variation in Twitter Emoticons," Univ. Pennsylvania Work. Pap. Linguist., 2012.

[4] N. A. Paramastri and G. Gumilar, "Penggunaan Twitter Sebagai Medium Distribusi Berita dan News Gathering Oleh Tirto.Id,” J. Kaji. Jurnalisme, 2019.

[5] H. Giles and T. Ogay, "Communication accommodation theory," in Explaining Communication: Contemporary Theories and Exemplars, 2006.

[6] N. Thakere, Jitendra, H. Giles, and J. CHeshire, "Psychological and linguistic parameters of speech accommodation theory," in Advances in the social psychology of, 2015.

[7] N. Coupland, J. Coupland, H. Giles, and K. Henwood, "Accommodating the elderly: Invoking and extending a theory1," Lang. Soc., 1988.

[8] A. Bell, "Language Style as Audience Design,” Lang. Soc., 1984.

[9] M. Ananny, "Networked press freedom and social media: Tracing historical and contemporary forces in press-public relations," J. Comput. Commun., 2014.

[10] K. Saddhono, A. Hasibuan, and M. I. Bakhtiar, "Facebook as A Learning Media in TISOL (Teaching Indonesian to Speakers of Other Languages) Learning to Support the Independency of Foreign Students in Indonesia,” J. Phys. Conf. Ser., vol. 1, 2019.

[11] K. Welbers and M. Opgenhaffen, "Presenting News on Social Media: Media logic in the communication style of newspapers on Facebook," Digit. Journal., 2019.

[12] S. Stieglitz and L. Dang-Xuan, "Emotions and information diffusion in social media Sentiment of microblogs and sharing behavior," J. Manag. Inf. Syst., 2013.

[13] M. A. Riordan, K. M. Markman, and C. O. Stewart, "Communication Accommodation in Instant Messaging," J. Lang. Soc. Psychol., 2013.

[14] U. Bunz and S. W. Campbell, "Politeness accommodation in electronic mail," Commun. Res. Reports, 2004.

[15] A. Bell, "Audience accommodation in the mass media," in Contexts of Accommodation, 2010.

[16] C. Gallois, T. Ogay, and H. Giles, "Communication Accommodation Theory: A Look Back and a Look Ahead," W.B. Gudykunst Theor. About Commun. Cult., 2005.

[17] J. W. Creswell, Research Design: Qualitative, Quantitative and Mixed Approaches (3rd Edition). 2009.

[18] R. Quirk, S. Greenbaum, G. Leech, and J. Svartvik, "A Comprehensive Grammar of the English Language Longman,” London New York, 1985.

[19] P. A. Anastasio, K. C. Rose, and J. Chapman, "Can the media create public opinion? A socialidentity approach,” Curr. Dir. Psychol. Sci., 1999. 